\title{
Pelatihan Surat Menyurat Elektronik Era 4.0 Siswa-Siswi di SMK Negeri 3 Kotabumi
}

\author{
Suripto*, Supriyanto, Akgis Cahya Ningtias
}

IImu Administrasi Bisnis, Universitas Lampung, Bandar Lampung, 35145, Lampung, Indonesia

\begin{abstract}
Abstrak.
Tujuan pengabdian ini adalah memberikan ketrampilan penulisan surat menyurat elektronik siswa di Jurusan Administrasi Perkantoran di SMK Negeri 3 Kotabumi. Untuk mengatasi permasalahan yang dihadapi para Siswa, pendampingan penulisan surat menyurat elektronik bagi para Siswa merupakan solusi yang tepat bagi permasalahan yang dihadapi para Siswa Jurusan Administrasi Perkantoran. Target jangka panjang yang akan dicapai dalam kegiatan ini adalah menjadikan Siswa terampil dalam menulis Surat Menyurat Elektronik yang akan digunakan sebagai bekal kelak menuju jenjang Perguruan Tinggi dan didunia pekerjaan atau masyarakat. Luaran dari kegiatan ini adalah artikel ilmiah shinta 4 Universitas Lancang Kuning, video kegiatan, dan profil hasil pengabdian yang dipublikasikan pada seminar hasil pengabdian Universitas Lampung. Metode yang digunakan adalah diskusi, ceramah dan membahas kasus-kasus yang menarik, tentang pengguna surat menyurat era 4.0. Dengan diadakannya pelatihan ini, diharapkan akan terbentuk motivasi yang kuat untuk menjadi seorang yang merintis sebuah administrasi profesional.
\end{abstract}

Keywords.

Surat Elektronik Era 4.0, Design Thinking, Pengembangan Teknologi

\section{PENDAHULUAN}

Menulis adalah kegiatan menuangkan perasaan, gagasan, ide, atau pendapat secara tertulis yang ditujukan untuk orang lain dengan memperhatikan kaidah kebahasaaan secara tidak langsung. Menulis sebagai salah satu keterampilan berbahasa perlu mendapat perhatian dalam pembelajaran di sekolah. Keterampilan menulis termasuk menulis surat elektronik akan memberikan jalan bagi siswa untuk memecahkan masalah ketika terjun di lapangan atau masyarakat. Belajar menulis surat dapat menghantarkan seseorang dalam menulis dan mengungkapkan sesuatu dengan baik dan benar. Bidang pendidikan merupakan salah satu bidang yang sangat dipengaruhi oleh teknologi informasi, baik dalam proses pembelajaran formal di sekolah maupun nonformal berupa pelatihan di luar sekolah. Dengan menggunakan Teknologi Informasi dan Komunikasi, suatu proses dan kegiatan dapat dilakukan dengan cepat, mudah dan efisien. Pembelajaran dengan TIK (Komputer) lebih baik dibandingkan dengan menggunakan metode konvensional. Pengembangan dan pemanfaatan media pembelajaran berbasis TIK baik yang bersifat offline maupun online,

\section{* Corresponding author: suriptob.1969@fisip.unila.ac.id}

Received 16 November 2020; Received in revised form 27 November 2020; Accepted 7 December 2020 Available online 24 December 2020

Lembaga Penelitian dan Pengabdian Kepada Masyarakat

Universitas Lampung 
bisa dimanfaatkan sebagai bahan masukan bagi pihak- pihak yang berminat terutama pihak pendidik.Oleh karena, itu penguasaan terhadap perangkat teknologi komunikasi perlu diajarkan pada semua tingkatan termasuk kepada siswa-siswi sekolah kejuruan [1,2].

Sekolah Menengah Kejuruan (SMK) adalah salah satu bentuk satuan pendidikan formal yang menyelenggarakan pendidikan kejuruan pada jenjang pendidikan menengah sebagai lanjutan dari SMP/MTs atau bentuk lain yang sederajat atau lanjutan dari hasil belajar yang diakui sama/setara SMP/MTs (UU Nomor 20 Tahun 2013, Pasal 18 ayat. Pendidikan kejuruan merupakan pendidikan menengah yang mempersiapkan peserta didik terutama untuk bekerja dalam bidang tertentu. SMK sebagai sekolah yang menyelenggarakan pendidikan kejuruan yang menerapkan program keahlian seperti teknik mesin, perkantoran, seni rupa, tata boga, administrasi dll mempunyai peran penting memberi bekal salah satunya hard skill yang menunjang profesional skill seperti memahami penggunaan komputer. Hard skill merupakan ketrampilan teknis dalam bidang ilmu pengetahuan dan teknologi yang diperoleh dari otodidak, bangku sekolah, kuliah, pelatihan. Siswa perlu memahami program yang terdapat di Windows, program yang paling sering digunakan di Windows adalah produk dari Microsoft [3,4].

Didalam dunia kerja yang berhubungan dengan administrasi perkantoran, penguasaan Microsoft Office sangat dibutuhkan sebagai tools pekerjaan administrasi perkantoran yang harus dikuasai oleh siswi SMK. Salah satu fungsi pendidikan adalah membekali siswa dengan kecakapan hidup dengan berbagai mata pelajaran yang mereka peroleh. Dengan bekal itu, siswa diharapkan mampu memecahkan masalah hidup yang mereka hadapi, termasuk dalam mencari atau menciptakan pekerjaan. Keterampilan menulis surat adalah salah satu bekal bagi siswa dalam mengatasi masalah di lapangan khususnya untuk memasuki dunia kerja. Oleh karena itu, yang perlu diperhatikan oleh guru adalah bagaimana memberikan kemudahan bagi siswa agar mereka mampu berinteraksi dengan lingkungan eksternal sehingga terjadi perubahan perilaku.

Selanjutnya, Sugiono mengidentifikasi beberapa hambatan pada level mikro/pelaku usaha, diantaranya yang paling dominan adalah belum meratanya kualitas sumber daya manusia/SDM yang masih minim, sehingga belum memungkinkan terbangunnya sebuah mindset pengguna surat menyurat era 4.0 yang baik dan benar, minimnya kreativitas, ide sehingga belum bisa menciptakan model bisnis yang diterima pasar dengan baik.Atau dengan kata lain, sustainability competitive advantage yang rendah. Belum meratanya kualitas SDM dan berbagai permasalahan diatas, menjadikan pelaku pengguna surat menyurat era 4.0 yang mampu berkontribusi terhadap perekonomian daerah/nasional masih didominasi di sebagian kecil wilayah yang ada di Pulau Jawa. Sedangkan wilayah di luar Pulau Jawa (khususnya Kota Bandar Lampung), masih belum berkontribusi secara significant. BPS (2018). SMK Negeri 3 Kotabumi adalah Salah Satu Sekolah Menengah Kejuruan yang unggul di Kotabumi. Dan sekolah tersebut memiliki Jurusan Administrasi Perkantoran.

Sejalan dengan kondisi di atas, Sebagai satu dari beberapa SMK yang fokus pada administrasi perkantoran, SMK Negeri 3 Kotabumi mempunyai visi untuk menyiapkan sumber daya manusia yang berkualitas di industri kerja, khususnya sub sektor administrasi. Lulusan SMK Industri Kerja ini diharapkan mampu, mencetak generasi muda yang siap menajdi pelaku pengguna surat menyurat era 4.0 di bidang industri kerja, khususnya sub sektor administrasi. Namun, pada kenyataannya, harapan tersebut, masih sulit terealisasi dengan berbagai hambatan. Berbagai hambatan tersebut diantaranya, pertama, mentalitas dan motivasi sebagai seorang pengguna surat menyurat era 4.0 pada umumnya masih rendah, sehingga sebagian besar lulusan dari SMKN ini masih berorientasi pada pencari kerja, bahkan bekerja di sektor yang tidak terkait dengan industri kerja [5]. Data dari pihak SMK menunjukkan bahwa sebagian besar lulusan, memilih untuk bekerja dari pada merintis dan memulai sebagai seorang pengguna surat menyurat era 4.0. Kedua, belum memahami design thinking yang baik dan benar untuk memulai dan mendesain model administrasi profesional yang baik. Berangkat dari kondisi tersebut, maka kegiatan tentang pelatihan tentang desain thinking untuk membangun pengguna surat menyurat era 4.0 di bidang industri kerja dikalangan siswa-sisw SMK Negeri 3 Kotabumi menjadi relevan untuk 
dilaksanakan.

\section{METODE}

\section{Metode}

Metode pelaksanaan kegiatan pengabdian yang akan dilaksanakan untuk mengatasi permasalahan adalah berikut ini.

\section{Metode Tutorial}

Metode ini digunakan untuk menjelaskan materi dasar dan pengetahuan tentang surat menyurat elektronik. Selain itu metode ini juga digunakan untuk memberikan pemahaman tentang pembuatan mail merge yang dapat digunakan untuk membuat gmail, yahoo, dan mengirim dan menerima surat elektronik pada gmail. Pada tahap pemberian materi, para peserta diberikan modul yang digunakan sebagai alat bantu dalam kegiatan pelatihan.

2. Metode Tanya Jawab

Metode ini digunakan untuk mengetahui sejauh mana pengetahuan peserta pelatihan terhadap materi yang telah dijelaskan.

3. Metode Praktik

Pada metode ini para siswa akan mempraktekkan semua materi yang telah dijelaskan sebelumnya. Metode ini digunakan untuk mengetahui sejauh mana pengetahuan dan kemampuan para siswa dalam membuat tugas mail merge untuk membuat gmail, yahoo, dan mengirim dan menerima surat elektronik pada gmail. Dan diakhir pelatihan peserta pelatihan akan diberikan angket respon para peserta terhadap pelatihan telah dilakukan.

\section{Kerangka Pemecahan Masalah}

Adapun kerangka pemecahan masalah dalam pelatihan Pelatihan Surat Menyurat Elektronik Era 4.0 Siswa-Siswi di SMK Negeri 3 Kotabumi dapat dilihat pada gambar dibawah ini.



Gambar 1. Kerangka Pemecahan Masalah. 


\section{Realisasi Pemecahan Masalah}

Untuk memecahan masalah dalam pencapaian memberikan informasi tentang penulisan surat menyurat elektronik dalam pembelajaran pada siswa SMK 3 Kotabumi maka perlu diadakannya pelatihan.

Dalam kegiatan pelatihan ini peserta diberikan penjelasan mengenai aplikasi gmail, yahoo dan pembuatan mail merge pada Ms. Word. Dalam pelaksanaan pelatihan ini akan melibatkan 3 (tiga) orang dosen dan dibantu oleh 3 (tiga) orang mahasiswa, hal ini dilakukan dengan tujuan agar kegiatan pelatihan ini mempunyai manfaat yang benar-benar dapat dirasakan oleh peserta pelatihan karena segala kesulitan-kesulitan peserta selama mengikuti pelatihan akan dapat diatasi dan peserta akan mendapatkan bimbingan yang optimal.

\section{HASIL DAN PEMBAHASAN}

\section{Hasil}

Kegiatan pelatihan ini diikuti oleh Siswa dan Guru SMKN 3 Kotabumi yang berjumlah 30 orang (absensi peserta terlampir). Untuk mengetahui pemahaman awal peserta tentang Surat Elektronik dan definisi surat elektronik, penggunaan dan cara mengoperasikanya di Era 4.0 dan pola kolaborasi antar seluruh peserta yang terlibat dalam pelatihan Penulisan Surat Menyurat Elektronik Era 4.0 Dikalangan Siswa-Siswi dan Guru Jurusan Administrasi Perkantoran dilakukan dengan menggunakan pre-test yang berbentuk pilihan ganda. Jumlah pre-test sebanyak 15 (lima belas) pertanyaan dan dikerjakan selama 30 puluh menit (soal pre-test terlampir). Materi pre-test merupakan rangkuman dari materi yang akan disampaikan dalam pelatihan. Kriteria hasil pre-test yang digunakan adalah sebagai berikut: (hasil pre-test dapat dilihat pada tabel 4.1)

a. Nilai $0-50$ : Belum memahami

b. Nilai $51-75$ : Cukup memahami

c. Nilai 76 - 100 : Sangat memahami

Berdasarkan hasil pre-test pada tabel 1 diketahui bahwa rata-rata tingkat pemahaman awal peserta adalah $68,6 \%$. Hal ini berarti peserta berada dalam kriteria Cukup memahami Surat Elektronik dan definisi surat elektronik, penggunaan dan cara mengoperasikanya di Era 4.0 dan pola kolaborasi antar peserta yang terlibat dalam pelatihan ini. Seluruh peserta masuk dalam kriteria belum memahami Surat Elektronik dan definisi surat elektronik, penggunaan dan cara mengoperasikanya di Era 4.0.

Tabel 1. Hasil Pre-test Pemahaman Awal Peserta

\begin{tabular}{clcc}
\hline No & \multicolumn{1}{c}{ Nama Peserta } & $\begin{array}{c}\text { Jumlah Jawaban } \\
\text { Benar }\end{array}$ & $\begin{array}{c}\text { Tingkat Pemahaman Awal } \\
\text { Peserta (\%) }\end{array}$ \\
\hline 1 & Anita & 11 & 64 \\
2 & Bagus Purlita Pujakesuma & 15 & 88 \\
3 & Cici Astuti & 13 & 76 \\
4 & Citra Dewi & 11 & 64 \\
5 & Dwi Teguh Pambudi & 13 & 76 \\
6 & Eko Saputro & 6 & 36 \\
7 & Etni Sri Wulantri & 14 & 82 \\
8 & Hana arie saputra & 13 & 76 \\
9 & lis Wanesti & 11 & 64 \\
10 & Imelda & 13 & 76 \\
11 & Lily diana fitri & 15 & 88 \\
12 & Mahlina & 7 & 42 \\
13 & Martini Sulistyowati & 12 & 70 \\
14 & Nia Rachmawati & 13 & 76
\end{tabular}




\begin{tabular}{llcc}
15 & Nurbaiti & 14 & 82 \\
16 & Putri Irmala Sari & 13 & 76 \\
17 & Riska fitria sary & 13 & 76 \\
18 & Riska Meirita & 10 & 58 \\
19 & Rissa Arifin & 13 & 76 \\
20 & Ristiani & 9 & 52 \\
21 & Rita Amelia Agustina & 12 & 70 \\
22 & Rizky & 14 & 82 \\
23 & Rizky Zanuar & 14 & 82 \\
24 & Ronald Rajagukguk & 14 & 82 \\
25 & Ruminawaty & 10 & 58 \\
26 & Rustantini & 8 & 46 \\
27 & Suparman & 10 & 58 \\
28 & Supi Ningsih & 12 & 70 \\
29 & Tuti.Mutia & 6 & 36 \\
30 & Yullia wati & 13 & 76 \\
& & & 68,6 \\
\hline
\end{tabular}

\section{Pembahasan}

Dalam rangka mengetahui pemahaman akhir peserta tentang Surat Elektronik dan definisi surat elektronik, penggunaan dan cara mengoperasikanya di Era 4.0 dan pola kolaborasi antar aktor yang terlibat dalam pelatihan ini dilakukan dengan menggunakan post-test yang berbentuk pilihan ganda. Soal post-test yang diberikan sama dengan soal pre-test dengan penambahan soal lebih banyak tujuan untuk mengetahui dampak dari pemberian materi selama pelatihan dan mengetahui progress peserta setelah pelatihan. Kriteria post-test yang digunakan sama dengan kriteria pre-test. Pemberian materi dilakukan secara tutorial (ceramah) yang dilanjutkan dengan dialog (tanya jawab) antara peserta dengan pemateri.
a. Nilai 0 - 50 : Belum memahami
b. Nilai $51-75$ : Cukup memahami
c. Nilai 76 - 100 : Sangat memahami

Proses pemberian materi diakhiri dengan diskusi, simulasi, dan pembahasan contohcontoh kasus. Hasil post-test dapat dilihat pada tabel 2.

Tabel 2. Hasil Pos-test Peserta

\begin{tabular}{clccc}
\hline No & \multicolumn{1}{c}{ Nama Peserta } & $\begin{array}{c}\text { Jumlah Jawaban } \\
\text { Benar }\end{array}$ & $\begin{array}{c}\text { Jumlah Jawaban } \\
\text { Salah }\end{array}$ & $\begin{array}{c}\text { Tingkat Pemahaman } \\
\text { Awal Peserta (\%) }\end{array}$ \\
\hline 1 & Anita & 13 & 7 & 76 \\
2 & Bagus Purlita Pujakesuma & 17 & 3 & 100 \\
3 & Cici Astuti & 15 & 5 & 88 \\
4 & Citra Dewi & 13 & 7 & 76 \\
5 & Dwi Teguh Pambudi & 15 & 5 & 88 \\
6 & Eko Saputro & 8 & 12 & 48 \\
7 & Etni Sri Wulantri & 16 & 4 & 94 \\
8 & Hana arie saputra & 15 & 5 & 88 \\
9 & lis Wanesti & 13 & 7 & 76 \\
10 & Imelda & 15 & 5 & 88 \\
11 & Lily diana fitri & 17 & 3 & 100
\end{tabular}




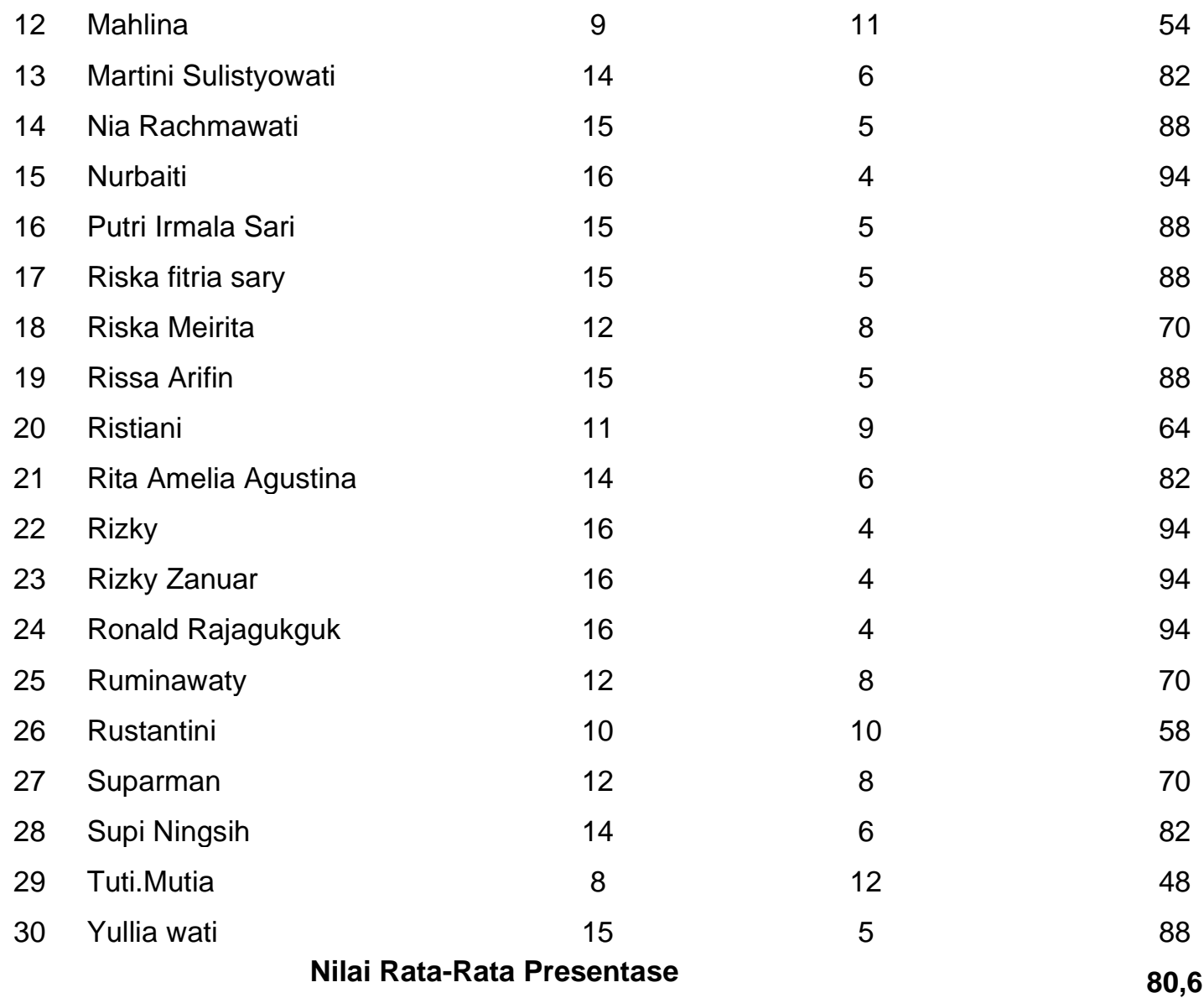

Berdasarkan hasil post-test pada tabel 5.2 diketahui bahwa rata-rata tingkat pemahaman akhir peserta adalah $80,6 \%$. Nilai ini masuk dalam kriteria sangat memahami. Jika dibandingkan dengan hasil pre-test berarti secara rata-rata telah terjadi peningkatan pemahaman peserta tentang Surat Elektronik dan definisi surat elektronik, penggunaan dan cara mengoperasikanya di Era 4.0 dan pola kolaborasi antar aktor yang terlibat dalam Pelatihan ini. Sebesar $19,4 \%$. Peserta yang memiliki kriteria belum memahami adalah $0 \%$. Hal ini berarti jika dibandingkan dengan hasil pre-test pemberian materi pelatihan berhasil meningkatkan $100 \%$ pemahaman peserta dari belum memahami ke kriteria yang lebih tinggi (sangat memahami). Namun belum mencapai $100 \%$ peserta yang mencapai kriteria sangat memahami. Sehingga perlu dipertimbangkan untuk menambah pelatihan dengan materi yang sama dan melakukan pendampingan jika ada kegiatan/program yang berkaitan dengan tema pelatihan ini.

Berdasarkan hasil kegiatan, dapat disimpulkan bahwa ada dua faktor penting penentu suksesnya kegiatan pengabdian ini yaitu metode dan media pembelajaran yang tepat dan sesuai dengan topik pembelajaran yang akan diajarkan. Metode dan media memiliki peran pembelajaran yang baik sangat efektif dalam pembelajaran [6]. Karena penggunaan metode dan media yang tepat dapat memberi stimulus bagi siswa khususnya siswa SMK untuk belajar aktif dan kreatif dan tentunya memiliki motivasi untuk meningkatkan pengetahuan mereka sesuai dengan bidang yang mereka pelajari.

\section{KESIMPULAN}

Kesimpulan Pelatihan Penulisan Surat Menyurat Elektronik Era 4.0 Dikalangan SiswaSiswi Jurusan Administrasi Perkantoran di SMK Negeri 3 Kotabumi, Lampung Utara adalah sebagai berikut : 
1. Rata-rata tingkat pemahaman awal 30 orang peserta Dikalangan Siswa-Siswi Jurusan Administrasi Perkantoran adalah 68,6\%. Seluruh peserta masuk dalam kriteria cukup memahami tentang Surat Elektronik dan definisi surat elektronik, penggunaan dan cara mengoperasikanya di Era 4.0 dan pola kolaborasi antar aktor yang terlibat dalam pelatihan ini.

2. Upaya yang dilakukan untuk meningkatkan pengetahuan dan pemahaman peserta pelatihan adalah dengan pemberian materi pelatihan tentang Surat Elektronik dan definisi surat elektronik, penggunaan dan cara mengoperasikanya di Era 4.0 dan pola kolaborasi antar aktor yang terlibat dalam pelatihan ini.

3. Rata-rata tingkat pemahaman akhir peserta adalah $80,6 \%$ dan nilai ini masuk dalam kriteria sangat memahami. Pemberian materi pelatihan berhasil meningkatkan 100\% pemahaman peserta.

\section{UCAPAN TERIMA KASIH}

Tim kegiatan pengabdian pada masyarakat mengucapkan terima kasih kepada Bapak Kepala Sekolah SMK Negeri 3 Kotabumi Drs.Zainal Abidin, M.Pd.I yang telah memberikan izin untuk dapat melaksanakan kegiatan ini dengan baik. Dan ucapan terima kasih sebesarbesarnya kepada LPPM Universitas Lampung yang telah mendanai kegiatan ini.

\section{DAFTAR PUSTAKA}

[1] Tedyyana, A. 2020. Implementasi Secure Socket Layer Pada Aplikasi Computer Assisted Test Komisi Pemilihan Umum Bengkalis. Digital Zone: Jurnal Teknologi Informasi Dan Komunikasi, 11(1), 71-80. https://doi.org/10.31849/digitalzone.v11i1.3859.

[2] Maulana, A., \& Wangdra, Y. 2020. Online Management System Berbasis Web Pada SMK Multistudi High School Batam. Digital Zone: Jurnal Teknologi Informasi Dan Komunikasi, 11(1), 1-10. https://doi.org/10.31849/digitalzone.v11i1.3197.

[3] Saputra, T., \& Utami, B. C. 2017. Implementation of Program the Village Empowerment in Riau Province. Jurnal Niara, 9(2), 50-57. https://doi.org/10.31849/nia.v9i2.2098.

[4] Sistem, I., \& Berdasarkan, P. 2018. Universitas lancang kuning pekanbaru 2018. 10(November 2018), 45-54.

[5] Saputra, T., Utami, B. C., \& Sufi, W. (2018). Pengaruh Persepsi Mahasiswa Terhadap Kualitas Pelayanan Pegawai Dibagian Administrasi Fakultas Ilmu Administrasi Universitas Lancang Kuning. Jurnal Niara, 11(1), 6-16. https://doi.org/10.31849/nia.v11i1.1520.

[6] Dharmawati, D. (2020). Pembelajaran Berbasis Komputer Menggunakan Ms. Office 2019 Pada Siswa Di Smk Dwitunggal 1 Tanjung Morawa. Dinamisia: Jurnal Pengabdian Kepada Masyarakat, 4(1). https://doi.org/10.31849/dinamisia.v4i1.3751 